\title{
PARADOKS PENDISIPLINAN AGAMA PADA MASYARAKAT TENGGER DI DESA NGADAS, KECAMATAN PONCOKUSOMO, KABUPATEN MALANG, JAWA TIMUR
}

\author{
Ni Putu Ayu Amrita Pradnyaswari \\ Fakultas Ilmu Sosial dan Ilmu Politik, Universitas Mahendradatta Denpasar \\ e-mail : erodhita@gmail.com
}

\begin{abstract}
Abstrak - Penelitian ini adalah karya asli yang ditulis dengan semangat emansipatoris tentang fenomena di masyarakat yang disebabkan oleh disiplin agama yang dilakukan oleh Bangsa melalui kehadiran agama resmi, dan penulisan tesis ini tidak memiliki niat untuk menempatkan pihak dalam tanggung jawab untuk ketidaknyamanan setelah tindakan itu. Alih-alih melindungi hak rakyat untuk memiliki keyakinan pada keyakinan mereka sendiri sebagaimana dinyatakan dalam konstitusi, Bangsa menekan masyarakat etnis yang memiliki kepercayaan lokal untuk masuk ke salah satu agama resmi di Indonesia, yaitu Islam, Katolik, Kristen, Hindu, Budha. Kesenjangan muncul ketika bangsa hanya mengakui agama "diimpor" sebagai agama resmi sementara kepercayaan lokal yang merupakan agama asli nenek moyang hanya dianggap sebagai pemujaan dan penganutnya dianggap sebagai "kafir" / kafir. Fenomena ini dapat dilihat pada masyarakat Tengger Brang Kidul yang tinggal di Ngadas, Kabupaten Malang, Jawa Timur.
\end{abstract}

Kata kunci: Tengger Brang Kidul, arena pertempuran agama, ideologi

\begin{abstract}
This research is an original work written with emancipatory spirit about the phenomenon in the society caused by the disciplinary of religion conducted by the Nation through the presence of official religions, and the writing of this thesis have no intention to put any party in responsibility for the inconvenience following that action. Instead of protecting the people's right to have faith in their own belief as stated in the constitution, the Nation suppresses ethnic societies who has local belief to convert into one of the official religions in Indonesia, namely Islam, Catholic, Christian, Hindu, Buddhist. A gap existed when the nation only recognized "imported" religions as the official religions while the local beliefs which are the original religions of the ancestors only considered as cults and their believers are considered as "kafir"/infidel. This phenomenon can be seen in the people of Tengger Brang Kidul who live at Ngadas, Malang Regency, East Java.
\end{abstract}

Keyword: Tengger Brang Kidul, religions battle arena, ideology

\section{PENDAHULUAN}

Agama dalam kenyataan hidup para pemeluknya akan bersentuhan dengan kepentingan-kepentingan aktual. Realitas empiris menunjukkan bahwa agama juga bersentuhan dengan politik, ekonomi, dan aspek-aspek duniawi lainnya yang bersifat konkrit (Nashir, 1999 : xviii). Gejala politisasi agama menjadikan ajaran-ajaran agama sebagai alat legitimasi perjuangan kekuasaan yang sarat pertaruhan. Hal tersebut berimplikasi pada terbentuknya tindakan-tindakan pragmatisme politik yang memperoleh penguatan dan legitimasi keagamaan. Politisasi agama dalam tindakan-tindakan politik pragmatis juga menghasilkan gejala sekularisasi politik yang bertopeng arogansi kekuasaan atas nama agama. Para elit yang berkuasa terus berusaha untuk memperjuangkan dan melanggengkan kekuasaan politiknya karena memperoleh "kekuatan moral" dari agama. Arogansi kekuasaan yang melingkupi penguasa di ruang politik menghasilkan penguasa yang despotik dengan mengatasnamakan agama, bahkan Tuhan. Kekuasaan politik memperoleh sejumlah idiom dan simbol-simbol religius-magis yang melahirkan praktik kekuasaan sewenang-wenang dan berkuasa untuk seumur hidup. Hal tersebut menegaskan bahwa agama adalah seperangkat ajaran yang sakral dan luhur dari Tuhan yang selanjutnya menemukan ruang sosio-historis yang 
empiris, profan, dan sarat kepentingan dalam kenyataan hidup para pemeluknya.

Keberadaan agama juga tidak dapat dilepaskan dari keyakinan agama tersebut terhadap kebenaran yang mengandung kebenaran mutlak. Kebenaran mutlak yang diyakini adalah agama yang dipeluk bersumber dari Tuhan dan bersifat absolut. Syamsul Arifin (2005:7) menyatakan bahwa masalah muncul ketika hal yang dianggap kebenaran mutlak dalam suatu agama dihadapkan dengan kebenaran mutlak yang berasal dari agama lain. Keyakinan terhadap kebenaran agama tersebut mempertebal klaim kebenaran (truth claim) sehingga memunculkan klaim penyelamatan (salvation claim) sebagai suatu hal yang tidak dapat dihindarkan. Kecenderungan absolutistik tersebut memunculkan kecenderungan ekspansionistik, yakni kecenderungan menyebarluaskan agama kepada orang lain. Alasan pertama yang mendorong sikap ekspansionistik adalah pandangan bahwa agama lain adalah tidak benar, kafir, sesat, dan perlu diluruskan kembali sehingga tindakan pelurusan kembali dipandang sebagai tugas suci yang harus dilaksanakan bagi setiap pemeluk agama. Alasan selanjutnya adalah bahwa penyebaran agama dianggap mampu memperkokoh komunitas keagamaan yang telah ada karena jumlah pemeluk agama dianggap mempengaruhi kekuatan agama tersebut.

\section{PEMBAHASAN}

Permasalahan yang dihadapi Indonesia yang berkenaan dengan isu agama adalah perihal kebebasan memeluk "agama". Hal tersebut dibuktikan dengan regulasi negara yang hanya mengakui agama-agama besar sebagai agama resmi, yakni Islam, Kristen, Katolik, Hindu, Buddha, dan Konghuchu, sesuai Penetapan Presiden No. 1 Tahun 1965 dan dinyatakan oleh UU No. 5 Tahun 1969. UU No. 23 Tahun 2006 tentang Administrasi Kependudukan juga menyatakan bahwa pemerintah Indonesia hanya mengakui Kristen, Katolik, Islam, Hindu, Buddha, dan Konghuchu sebagai agama resmi. Padahal di satu sisi, Indonesia merupakan negara multikutural yang terdiri dari beragam etnik dengan kepercayaan dan bentuk-bentuk kearifan lokal di dalamnya. Frans Magnis Suseno (2013:41) menyatakan bahwa agama-agama asli dan agama-agama "Timur" memposisikan Tuhan sebagai suatu yang imanen, yakni ketuhanan tidak dapat dipisahkan dari alam, berbeda dengan agama dari rumpun Abrahamik yang memandang Tuhan sebagai suatu yang transendental yang tidak bercampur dengan alam. Kepercayaan-kepercayaan tersebut merupakan "agama asli"" masyarakat Indonesia yang merupakan warisan dari nenek moyang mereka, manusia Indonesia. Kesenjangan terlihat ketika negara hanya menetapkan agama-agama besar yang bukan asli Indonesia sebagai agama resmi yang diakui pemerintah. Realitas empiris yang memperkuat gagasan tersebut adalah negara membuat dan memiliki regulasi untuk menempatkan agama resmi di bawah asuhan Departemen Agama, namun menempatkan aliran kepercayaan di bawah asuhan Biro Pakem (Pengawas Aliran Kepercayaan Masyarakat) Kejaksaan yang dibentuk pada tahun 1960. Tugas Biro Pakem pada saat itu adalah mengkoordinasi tugas pengawasan terhadap aliran-aliran kepercayaan dalam masyarakat bersama instansi-instansi pemerintah lainnya utuk kepentingan keagamaan dan ketertiban umum (Baso, 2005 : 240). Lembaga Pakem kemudian menjadi bersifat nasional dan didirikan di tiap provinsi dan memiliki tugas-tugas yang lebih spesifik yakni pengawasan diarahkan pada gejala-gejala yang dapat menghalangi jalannya pembangunan, seperti ajaran-ajaran atau gerakan-gerakan yang dapat menimbulkan gangguan ketertiban/ keamanan umum; dan ajaran-ajaran atau gerakan-gerakan yang dapat merugikan para pengikutnya atau masyarakat umumnya di bidang mental/spiritual dan material. Dalam hal suatu gerakan agama/aliran kepercayaan menampakkan tanda-tanda dan kecenderungan ke arah kesesatan, maka

\footnotetext{
1 Menurut Purwadi Soeriadiredja (Soeriadiredja, 2012:12), agama asli adalah sistem keyakinan dan segala aspek yang meliputinya serta tata-cara peribadatannya didasarkan pada aturan-aturan atau nilai-nilai sosial-budaya yang berlaku dalam masyarakat yang bersangkutan, yang diwariskan secara turun-temurun dari nenek moyang mereka. Menurut Subagya (1979:13) yang dimaksud dengan "agama asli" ialah kerohanian khas dari satuan bangsa atau dari suku bangsa, sejauh itu berasal dan dikembangkan di tengah-tengah bangsa itu sendiri dan tidak dipengaruhi oleh kerohanian bangsa lain atau menirunya. Kerohanian itu itu dan tumbuh secara spontan bersama (suku) bangsa itu sendiri. Dia murni tak bercampur dengan kerohanian agama lain dan pada hakekatnya hanya terdapat pada masyarakat yang tertutup terhadap pergaulan antar (suku) bangsa. Oleh karena itu, agama semacam itu disebut juga agama etnis, agama suku, agama preliterate atau agama sederhana.
} 
Tim Pakem harus mengambil tindakan pencegahan (Baso, 2005:242).

Hal tersebut bertolak belakang dengan UUD RI (setelah amandemen ke-4) Bab X A tentang Hak Asasi Manusia Pasal 28E (1) Setiap orang bebas memeluk agama dan beribadat menurut agamanya, memilih pendidikan dan pengajaran, memilih pekerjaan, memilih kewarganegaraan, memilih tempat tinggal di wilayah negara dan meninggalkannya serta berhak kembali lagi, (2) Setiap orang berhak atas kebebasan meyakini kepercayaan, menyatakan pikiran, dan sikap sesuai hati nuraninya. Pasal 28 I (2) Setiap orang berhak bebas dari perlakuan yang bersifat diskriminatif atas dasar apapun dan berhak mendapat perlindungan terhadap perlakuan yang diskrimantif itu, (3) identitas budaya dan hak masyarakat tradisonal dihormati selaras dengan perkembangan zaman dan peradaban. Bab XI tentang Agama Pasal 29 (1) Negara berdasar atas Ketuhanan Yang Maha Esa, (2) Negara menjamin kemerdekaan tiap-tiap penduduk untuk memeluk agamanya masing-masing dan untuk beribadat menurut agamanya dan kepercayaannya itu.

Salah satu masyarakat di Indonesia yang masih meyakini nilai dan kepercayaan warisan nenek moyang adalah masyarakat Tengger ${ }^{2}$. Tengger adalah komunitas adat yang merupakan bagian dari suku Jawa yang secara administratif menempati 4 wilayah kabupaten, yakni Malang, Probolinggo, Lumajang, dan Pasuruan. Masyarakat Tengger memiliki sebutan khusus untuk mengidentifikasi anggota komunitas etnik mereka yang terse-

\footnotetext{
2 Tengger secara etimologis (Widyaprakosa, 1994:26) memiliki arti berdiri tegak atau diam dan tidak bergerak. Pengertian Tengger jika dikaitkan dengan kepercayaan yang hidup dalam masyarakat dapat diartikan tenggering budi luhur. Tengger juga memiliki arti sebagai tanda atau cirri yang memberikan sifat khusus pada sesuatu. Pengertian Tengger dapat dikatakan sebagai sifat-sifat budi pekerti luhur. Tengger juga memiliki pemaknaaan lain dalam kepercayaan masyarakat pendukungnya. Sebutan Tengger tidak terlepas dari legenda nenek moyang masyarakat Tengger. Legenda Rara Anteng dan Jaka Seger merupakan sejarah yang diyakini masyarakat Tengger sebagai awal mula keberadaan mereka. Rara Anteng dan Jaka Seger adalah sepasang suami-istri yang memiliki 25 anak, namun salah satu diantaranya menjadi tumbal dengan dijerumuskan ke dalam kawah Bromo demi keselamatan keluarganya. Dalam kisah ini, Tengger merupaka akronim dari kata "teng" dari Rara Anteng dan "ger" dari Joko Seger. Anteng memiliki makna kedamaian dan seger memiliki maka kesuburan. Hal tersebut tercermin pula dalam kehidupan masyarakat Tengger yang penuh kedamaian, hidup sederhana, gotong royong, dan toleran.
}

bar di beberapa daerah, misalnya sebutan Brang Lor (utara) untuk masyarakat yang tinggal di wilayah Probolinggo, Brang Kulon (barat) untuk wilayah Pasuruan, Brang Wetan (timur) untuk wilayah Lumajang, dan Brang Kidul (selatan) untuk wilayah Malang. Pusat kebudayaan masyarakat Tengger masih dapat dilihat pada beberapa desa yang memiliki akses terdekat dengan gunung Bromo, seperti Desa Ngadisari di Kabupaten Probolinggo, Desa Wonokitri di Kabupaten Pasuruan, Desa Ranupani di Kabupaten Lumajang, dan Desa Ngadas di Kabupaten Malang. Masyarakat yang hidup di daerah tersebut masih memiliki kepercayaan lokal yang berorientasi pada Gunung Bromo. Kepercayaan lokal masyarakat tersebut tetap hidup dan dibalut dalam warna agama yang mereka miliki. Agama yang mereka peluk adalah agama resmi yang diakui pemerintah, seperti Hindu, Buddha, Islam, dan Kristen.

Kondisi wilayah yang strategis, tanah yang subur, pemandangan yang indah, dan kekayaan budaya menjadi potensi tersendiri bagi masyarakat ini, khususnya di bidang pariwisata. Pariwisata memberikan pengaruh signifikan bagi masyarakat Tengger karena pariwisata turut andil mengenalkan masyarakat Tengger pada eksternalitasnya, seperti negara, misionaris agama, media, pemodal, dan sebagainya. Hal tersebut membuat Tengger menjadi medan yang dianggap cukup strategis untuk para agen berkontestasi merebut hati masyarakat untuk memeluk agama-agama besar melalui proses infiltrasi, baik pasif maupun aktif. Infiltrasi aktif dilakukan sejak abad XVIII Masehi dengan ditandai peperangan yang dilakukan oleh orang Islam dari Madura (Hefner, 1999:13) dan selanjutnya konflik di tahun 1965 berkenaan dengan Partai Komunitas Indonesia (PKI). PKI merupakan suatu organisasi yang memiiki stigma antiagama, ideologi komunis, maupun agama komunis sehingga pemeluk agama selain Islam dan Kristen dianggap anggota PKI (Hefner, 1984:243).

Infiltrasi pasif juga menjadi bagian dari dinamika kehidupan masyarakat Tengger. Pada awal tahun 1980-an kebangkitan agama Hindu di Tengger makin marak. Pada waktu itu pemerintah kembali menggalakkan upacara-upacara adat di Tengger. Pada tahun 1986 almarhum Sudja'i (Ketua Paruman Dukun Pandhita se-Tengger pada 
saat itu) pernah juga mengajak beberapa tokoh Tengger yang tetap mempertahankan agama Buda ${ }^{3}$ Tengger untuk memeluk agama Hindu, tetapi sebagian kecil menolak. Hal yang sama dilakukan Pak Mudjono pada tahun 2004. Tetapi beberapa tokoh tetap bersikukuh menjadi Buda. Masyarakat Tengger meyakini bahwa Buda merupakan kepercayaan asli masyarakat sebelum adanya peng"agama"an yang dilakukan pemerintah. Buda adalah suatu kepercayaan yang khas kejawen dan bukan bagian dari agama Buddha ${ }^{4}$ yang diakui pemerintah sebagai agama resmi.

Saat ini Hindu di Desa Wonokitri, Kabupaten Pasuruan juga menjadi semacam cermin bagi Hindu Bali mainstream. Masyarakat di Desa Wonokitri sudah banyak mengadopsi kepercayaan dan ritual masyarakat Hindu Bali, bahkan beberapa ritual khas warisan nenek moyang, seperti khitan sudah tidak lagi dilakukan. Beberapa anggota masyarakat juga beternak babi. Berbeda dengan Wonokitri, dinamika masyarakat dalam bidang kepercayaan juga dialami masyarakat Desa Ranupani yang $1 / 3$ wilayahnya kini telah dikuasai pendatang (diluar orang Tengger) yang tidak menyesuaikan diri mengikuti tradisi orang Tengger pada umumnya. Kenyataan di lapangan juga memperlihatkan bahwa tingkat kesejahteraan pendatang lebih baik dari pada penduduk asli setempat. Masyarakat Tengger Brang Lor, Wetan, dan Kulon memiliki interaksi yang kuat dengan pariwisata dan bersifat terbuka sehingga memungkinkan penduduk luar Tengger untuk tinggal bahkan menetap di wilayah tersebut. Hal ini berbeda dengan masyarakat Tengger Brang Kidul yang tinggal di Desa Ngadas, Kabupaten Malang.

Desa Ngadas memiliki penduduk mayoritas yang beragama Buddha. Sekte Buddha yang mereka yakini adalah Buddha Jawa Sanyata dengan pusat orientasi adalah Hyang Wenanging Jagat dan keyakinan Buda sebagai bagian dari keyakinan Tengger, walaupun setelah tahun 1990-an, beberapa yang dicirikan mereka mengikuti aliran Buddha Maitreya. ${ }^{5}$ Masyarakat

3 Buda (Baca: Budo) merupakan agama asli Tengger yakni merupakan agama Siwa-Buddha yang juga menjadi agama resmi Kerajaan Majapahit (Sashangka, 2011:423) 4 Buddha adalah agama resmi negara yang diakui pemerintah Republik Indonesia.

5 Aliran Maitreya merupakan salah satu aliran yang diterima, diakui, dan menjadi bagian dari Perwakilan Umat Buddha Indonesia (Walubi).
Tengger Brang Kidul di Desa Ngadas hingga saat ini masih meyakini Hyang Wenanging Jagat sebagai Tuhan mereka. Kitab suci yang mereka yakini adalah Adam Makna, meskipun saat ini masyarakat sudah mulai mengenal Tripitaka dan Siddharta Gautama sebagai pusat orientasi mereka yang baru. Konversi ke agama besar banyak dilakukan dari anggota masyarakat yang beralih menjadi pemeluk agama Islam. Masyarakat Desa Ngadas bukan merupakan masyarakat majemuk yang terdiri dari banyak penduduk pendatang. Masyarakat Desa Ngadas merupakan masyarakat asli Tengger yang sudah lama tinggal dan menetap di daerah tersebut sehingga proses perebutan hegemoni agama dalam desa tersebut sesungguhnya hanya dilakukan di internal masyarakat.

Kompleksitas kehidupan masyarakat Tengger di Desa Ngadas mengalami gejolak ketika terjadi tragedi nasional pemberontakan G30 S/PKI pada tahun 1965. Tragedi nasional tersebut telah menimbulkan gejolak-gejolak politik di Indonesia sehingga mengakibatkan terjadinya pembantaian besar-besaran terhadap orang-orang komunis. Berkembang wacana bahwa orang ataupun masyarakat yang tidak memeluk agama Islam atau Kristen dituduh komunis sehingga menimbulkan ketakutan bagi masyarakat Tengger non-Muslim dan akhirnya sebagian masyarakat memilih unuk masuk ke dalam agama Islam agar selamat (Hefner, 1985:243). Fenomena serupa juga terjadi pada kepercayaan Wetu Telu di Lombok di mana kaum Wetu Telu seolah berada dalam tekanan agresi kultural kaum Waktu Lima melalui proses monoteisme dan egaliterianisme Islam yang lebih ortodoks (Budiwanti, 2000:345).

Salah satu agen yang juga dapat dikatakan paling berpengaruh pada pembentukan identitas manusia Tengger di Desa Ngadas adalah melalui peran negara. Negara mulai menghegemoni kebebasan beragama masyarakat melalui dibentuknya badan yang disebut Badan Koordinasi Pengawas Aliran Kepercayaan Masyarakat (Pakem) Kejaksaan Republik Indonesia dan Undang-Undang Nomor 1/PNPS/1965 tentang Pencegahan Penyalahgunaan Agama dan atau Penodaan Agama. Kemunculan paket kebijakan tersebut tidak dapat dilepaskan dari situasi sosial poli- 
tik pascakemerdekaan. Niels Mulder dalam Kholiludin (2009:151) menyatakan bahwa Departemen Agama pada tahun 1953 mencatat bahwa terdapat lebih dari 360 kelompok kebatinan yang terdapat di wilayah Jawa yang memiliki peran dalam kehidupan masyarakat sehingga partai-partai Islam pada Pemilu 1955 gagal memperoleh suara mayoritas (hanya mendapat $42 \%$ suara).

Pada tahun 1952 diadakan sidang Dewan Perwakilan Rakyat yang mengusulkan agar Departemen Agama membuat rumusan definisi agama sehingga saat itu muncul rumusan unsure-unsur esensial agama berupa nabi/rasul, kitab suci, dan pengakuan dari luar negeri. Hal tersebut membuat kalangan Hindu Bali tidak menyetujui rumusan tersebut sehingga definisi agama tidak pernah muncul dalam regulasi. Pada tahun 1953, Departemen Agama melaporkan adanya 360 agama baru di Indonesia sehingga muncul kebijakan yang menempatkan Pakem sebagai salah satu biro di bawah struktur Departemen Agama. Pakem merupakan akronim dari Pengawas Aliran Kepercayaan Masyarakat, meskipun di beberapa daerah muncul pemaknaaan berbeda mengenai definisi Pakem. Ada yang memahami sebagai pengawas preventif, ada yang memaknai hanya sebagai Peninjau Aliran Kepercayaan Masyarakat, dan ada yang memaknai sebagai Penelitian dan Pengembangan Aliran Masyarakat (Kholiludin, 2009:153). Pada tahun 1958, Kejaksaan Agung membentuk Bagian Gerakan Agama dan Kepercayaan Masyarakat dan selanjutnya diresmikan menjadi Biro Pakem pada tahun 1960. Pada tahun 1961, Biro Pakem didirikan di setiap provinsi dan kabupaten melalui Surat Edaran Departemen Kejaksaan Biro Pakem Pusat No. 34/Pakem/S.E./61 tanggal 7 April 1961 dengan tugas mengikuti, memperhatikan, mengawasi, gerak-gerik, serta perkembangan dari semua gerakan agama, semua aliran kepercayaan/kebatinan, baik yang berasal dari dalam, maupun luar negeri. Tugas Pakem disempurnakan dalam Surat Instruksi Jaksa Agung No. 1/Insr/Secr/1963 tanggal 5 Februari 1963 tentang Penyelesaian Persoalan di Bidang Pakem Kejaksaan yang menegaskan pada pengawas yang diarahkan pada gejala-gejala yang dapat menghalangi jalannya pembangunan (Baso, 2005:242-243).
Konstitusi yang mulai mendiskriminasi kepercayaan lokal terhadap dibentuknya Undang - Undang No. 16 Tahun 2004 mengenai Tugas Pengawasan Aliran Kepercayaan tercantum pada Bab III Pasal 30 Ayat 3 (d). Peraturan serupa juga terdapat dalam Undang-Undang No. 5 Tahun 1991 dalam Bab III Pasal 27 Ayat 3 (d) dan Undang-Undang No. 15 Tahun 1961 dalam Bab I Pasal 2 Ayat 3. Pada tanggal 27 Januari 1965, Penetapan Presiden (PP) No. 1 (selanjutnya ditulis PNPS 1965) dikeluarkan oleh Soekarno tentang Pencegahan Penyalahgunaan dan atau Penodaan Agama. Status PP ini kemudian ditingkatkan sebagai Undang-Undang melalui Penetapan Undang-Undang No. 5 Tahun 1969 yang dalam perkembangannya menjadi alat untuk membentengi agama resmi dari aliran-aliran kepercayaan (Kholiludin, 2009:159).

Penegasan dikotomi agama resmi yang diakui negara juga dapat dilihat dalam UUDS 1950 Pasal 43 ayat 3 dan UUD RIS Pasal 41 Ayat 1 dan 2. Hal tersebut menguatkan bahwa negara memiliki wewenang untuk memberikan pengakuan resmi, memberikan perlindungan, dan bantuan hanya kepada agama resmi (Baso, 2005:239). Dasar legal formal mengenai diskursus agama resmi tersebut dikukuhkan oleh konsttusi negara. Perjalanan panjang "kebijakan" negara tersebut juga berpengaruh pada kehidupan beragama masyarakat Indonesia pada umumnya, dan masyarakat Tengger di Desa Ngadas pada khususnya.

Agama merupakan suatu bentuk ideologi yang berada pada kognitif masyarakat pemeluknya. Wacana mengenai agama menjadi situs yang paling kental dalam hubungannya dengan kekuasaan, pengetahuan, dan kebenaran. Agama dapat menjadi sumber diskriminasi dan dominasi para pemeluknya. Mekanisme ideologi tersebut menunjukkan bahwa agama tidak lepas dari fenomena ideologi, sehingga fenomena radikalisme dan diskriminasi dengan mengatasnamakan agama adalah bagian dari fungsi agama sebagai ideologi. Pertarungan ideologi tersebut menghasilkan suatu pergulatan makna. Pergulatan makna dilakukan oleh agen yang membawa ideologi kebenaran agama besar mereka dan agen yang tetap mempertahankan ideologi lama sebagai warisan nenek moy- 
ang. Pergulatan makna yang terjadi pada masyarakat Tengger Brang Kidul di Desa Ngadas ditandai dengan hubungan dialogis dan kompromistis antaragen sehingga terjadi negosiasi yang dianggap relevan dalam kehidupan masyarakat setempat. Ideologi kebenaran absolut agama dan sarat kekuasaan dimiliki oleh agen yang memiliki keinginan untuk menginfiltrasi masyarakat di Desa Ngadas. Di sisi lain, masyarakat di Desa Ngadas juga mempertahankan ideologi primordial mereka yang tetap mempertahankan tradisi dan keyakinan mereka terhadap nenek moyang.

\subsection{Ideologi Kebenaran Absolut Agama}

Fenomena yang terjadi dalam agama adalah agama terkesan memberikan landasan ideologis dan pembenaran simbolis yang berfungsi sebagai alibi pribadi dan peneguhan tekad, mempertajam perbedaan, dan memistiskan motif pertentangan menjadi perjuangan membela kebenaran dan keimanan dengan mengatasnamakan Tuhan. Pemistisan motif tersebut membuat konflik berubah bentuk menjadi perjuangan yang mempertaruhkan tujuan akhir keberadaan manusia. Setiap kompromi akan dianggap sebagai kelemahan atau penghianatan. Motif konflik menjadi irasionalitas yang tercermin dalam mencampuadukkan kepentingan pribadi atau kelompok dengan mengatasnamakan kehendak Tuhan. Para pemuka agama tidak dapat mengelak dari tanda tiadanya unsur kritis dan tidak berfungsinya rambu-rambu pengarah pemahaman ataupun penafsiran. Kehendak Tuhan hendak ditangkap secara langsung dengan ketelanjangan dan egoisme kemampuan manusia. Para pemuka agama terkadang tidak menyadari bahwa antara ajaran (pengetahuan) dan tindakan masih terdapat jarak. Jarak ini sering kali tidak disadari sehingga muncul anggapan bila sudah diajarkan maka dianggap sudah dilaksanakan. Keyakinan dan ajaran tidak otomatis menyatu menjadi sistem tindakan. Agama yang dianggap konkrit adalah yang dapat dihayati oleh pemeluknya dengan sistem ajaran, norma, moral, institusi, ritus, simbol, dan para pemukanya. Semua unsur pembentuk wajah konkrit ini dapat mengkristal menjadi sebuah bentuk "penafikan" pada "yang berbeda". Pada kondisi tersebut, unsur provokasi dapat menyulut terjadinya konflik (Haryatmoko, 2010:82-83).
Nelson-Pall Meyer mengajukan tesis bahwa kekerasan religius yang dilakukan para penganut agama monotheis (yudaisme, kristianisme, dan Islam), tidak semata-mata masalah distorsi dalam penafsiran teks-teks suci. Kekerasan tersebut lebih berakar dalam tradisi kekerasan seakan-akan Tuhan mehendaki kekerasan dan hal ini dianggap sebagai sebuah kebenaran. Pemahaman akan tradisi kekerasan Tuhan ini, otoritas agama takut mempertanyakannya karena seakan-akan mengancam kebenaran pesan Tuhan dan menggoyahkan dasar keimanan. Kekerasan dalam agama gambaran Tuhan yang menonjol ialah Tuhan sebagai penghukum, penganiaya, pemaksa, pembalas dendam, dan sewenang-wenang. Gambaran tersebut menghentak rasa keagamaan antaragama maupun intern agama itu sendiri. Gambaran mengenai sifat kekerasan Tuhan merupakan proyeksi sifat kekerasan yang dimiliki manusia dengan mengatasnamakan Tuhan. Kekerasan Tuhan tampil sebagai kesucian sehingga kekerasan dianggap sebagai suatu kebenaran. Kekerasan Tuhan disamarkan dalam bentuk pembebasan dan pertobatan yang terkesan memiliki fungsi korektif dan liberatif (Haryatmoko, 2010:85-103).

Keberadaan agama juga tidak dapat dilepaskan dari keyakinan agama tersebut terhadap kebenaran yang mengandung kebenaran mutlak. Kebenaran mutlak yang diyakini adalah agama yang dipeluk bersumber dari Tuhan dan bersifat absolut. Syamsul Arifin (2005:7) menyatakan bahwa masalah muncul ketika hal yang dianggap kebenaran mutlak dalam suatu agama dihadapkan dengan kebenaran mutlak yang berasal dari agama lain. Keyakinan terhadap kebenaran agama tersebut mempertebal klaim kebenaran (truth claim) sehingga memunculkan klaim penyelamatan (salvation claim) sebagai suatu hal yang tidak dapat dihindarkan. Kecenderungan absolutistik tersebut memunculkan kecenderungan ekspansionistik, yakni kecenderungan menyebarluaskan agama kepada orang lain. Alasan pertama yang mendorong sikap ekspansionistik adalah pandangan bahwa agama lain adalah tidak benar, kafir, sesat, dan perlu diluruskan kembali sehingga tindakan pelurusan kembali dipandang sebagai tugas suci yang harus dilaksanakan bagi setiap pemeluk agama. Alasan selanjutnya adalah bahwa penyebaran agama di- 
anggap mampu memperkokoh komunitas keagamaan yang telah ada karena jumlah pemeluk agama dianggap mempengaruhi kekuatan agama tersebut.

Suatu kelompok sosial secara naluriah memiliki keinginan untuk menjaga identitasnya agar tetap murni dan menolak yang berbeda. Kehadiran pihak yang berbeda agama dapat mengancam diri. Fungsi ideologis agama adalah sebagai pembenaran kekuasaan dan landasan simbolis kekerasan. Peran pemimpin agama sangat sentral dalam menanamkan kebencian terhadap pemeluk agama lain dan menolak yang dianggap berbeda. Interaksi komunikasi dalam memberi makna tergantung pada kerangka dan kemampuan penafsiran untuk melihat realitas dan hubungan dengan umat beragama lain. Tugas mereka seharusnya adalah untuk menunjukkan wajah damai agama, penerimaan pluralitas, dan toleransi. Namun ketika penafsiran menjadi sangat politis dan penuh kepentingan, peran guru agama dan pemuka agama itulah yang sebenarnya sangat menentukan. Masuknya kepentingan politik bukan merupakan cara berpikir yang dipaksakan, tetapi merupakan perpanjangan dari cara berpikir yang telah ditanamkan oleh para pemuka agama. Kebenaran tunggal (single truth) dianggap sebagai sebuah paradigma kebenaran, bukan wajah kebenaran itu sendiri (Iyubenu, 2015:13).

\subsection{Ideologi Kekuasaan}

Pertarungan simbolik selalu menempatkan kekuatan-kekuatan untuk memonopoli visi yang sah terhadap dunia sosial dan memaksa kebenaran pandangan suatu kelompok atas kelompok lain. Kompetisi antaragen dalam pertarungan simbolik memiliki tujuan akhir yang sama yakni memperoleh kekuasaan. Kekuasaan yang dituju berupa kekuasaan untuk mengontrol ideologi, persepsi, visi, maupun cara pandang seseorang ataupun masyarakat. Ajang perebutan kekuasaan harus dimaknai sebagai upaya memproduksi dan menampilkan pandangan dunia yang paling diakui kebenarannya. Hal tersebut bermuara pada kepentingan untuk mendapatkan legitimasi bahwa pandangan tertentu adalah pandangan yang paling sah dibandingkan yang lain atau disebut dengan kekuasaan simbolik. Kekuasaan simbolik merupakan suatu kekuasaan untuk mengkonstruksi re- alitas melalui tatanan gnosociological, yaitu pemaknaan yang paling dekat mengenai dunia sosial satu kelompok kelompok atau individu.

Sebuah kekuasaan simbolik tidak dikenali betuk aslinya tapi tetap diakui sebagai konsensus. Kekuasaan simbolik beroperasi dengan mengunakan simbol-simbol sebagai instrumen pemaksa terhadap kelompok subordinat yang memiliki peran dalam mereproduksi tatanan sosial sesuai dengan keinginan kelompok dominan. Kekuasaan simbolik sangat bergantung pada modal simbolik dan efektivitas simbolik dimana strategi investasi simbolik bekerja. Semakin besar seseorang orang atau kelompok yang memiliki modal simbolik maka peluang tersebut merupakan kredit bagi terbentuknya ototritas sosial yang diporeleh dari pertarungan sebelumnya. Efektivitas simbolik bekerja atas padangan yang ditawarkan sesuai dengan strategi investasi simbolik yang dijalankan. Kekuasaan simbolik dalam konteks ini merupaka sebuah kekuasaan petasbihan, sebuah kekuasaan yang dijalankan dengan halus agar tidak dikenali dan disadari sehingga kelompok yang didominasi menyerahkan dirinya untuk masuk dalam lingkaran dominasi. Dominasi dalam bentuk ini disebut Bourdieu sebagai kekerasan simbolik, yaitu kekrasan yang lembut dan tak kasat mata. Mekanisme objektif yang diciptakan kekerasan simbolik memanfaatkan simbol-simbol yang ada untuk memenuhi fungsi politiknya, yaitu kehendak untuk berkuasa. Sistem kekuasaan meuntut mereka untuk mendominasi dan meyebarkan pengaruh-pengaruh ideologis atau memaksakan pandangan kelompok dominan pada kelompok marginal. Kekerasan simbolik dialankan melalui 2 mekanisme yakni eufemisasi dan cencorship. Eufemisasi yaitu mekaisme yang menjadikan kekerasan simbolik tidak terlihat, berangsung secara halus, serta mendorong orang untuk menerima apa adanya. Cara ini dilakukan dengan melembutkan ekspresi, wacana, maupun bahasa kedalam bentuk-bentuk filosofis yang bersifat abstrak. Cencorship juga beroperasi dengan memproduksi wacana ilmiah yang dibangun dengan teks tertulis dengan tujuan untuk menentukan apa yang boleh dan tidak boleh dikatakan dalam rangka pelestaran nilai-nilai utama. Kekerasan simbolik bekerja melalui dominasi bahasa, gaya hid- 
up, cara berfikir, cara berbicara, dan cara bertindak (Fashri, 2004:141-144).

Perbedaan yang ditekankan untuk memberi corak identitas dimanfaatkan untuk kepentingan diri ataupun kelompok. Terdapat 3 mekanisme pokok yang menentukan kaitan agama dan politik: kerangka penafsiran religious terhadap hubungan sosial (fungsi ideologi), agama sebagai faktor identitas, dan legitimasi etis hubungan sosial. Pertama, fungsi agama sebagai ideologi adalah sebagai perekat masyarakat karena memberi kerangka penafsiran dalam pemaknaan hubungan sosial sejauh mana suatu tatanan sosial dianggap sebagai representasi religious yang dikehndaki Tuhan. Kedua, agama sebagai faktor identitas dapat didefinisikan sebagai kepemilikan pada kelompok sosial tertentu. Kepemilikan ini member stabilitas sosial, status, pandangan hidup, cara berpikir, etos. Hal tersebut dapat mengental bila dikombinasikan dengan identitas etnis, misalnya Aceh Musli, Flores Katolik, Bali Hindu yang mampu menjadi alat perekat, meski di sisi lain juga mampu menjadi alat diskriminasi. Ketiga, agama menjadi legitimasi etis hubungan sosial dan bukan merupakan sakralisasi hubungan sosial, tetapi suatu tatanan sosial yang mendapat dukungan dari agama. Formalisme agama menjadi unsur penting dalam penghayatan karena terkait dengan masalah pengakuan sosial dan kebanggan pada kepemilikan kelompok. Maka butuh penamaan suatu sistem sosial, ekonomi, budaya, dengan jargon-jargon agama yang akan meningkatkan fanatisme pemeluknya (Haryatmoko, 2010:84).

\subsection{Anchestor Worship dan Ideologi Pri- mordial}

Pendewaan dan pemitosan roh nenek moyang melahirkan proses penyembahan roh nenek moyang (ancestor worship) yang selanjutnya mendorong timbulnya hukum adat, kebudayaan, dan relasi-relasi pendukungnya. Fungsi roh nenek moyang merupakan pengemong dan pelindung keluarga yang masih hidup dan sering kali dipersonifikasikan dalam tokoh pewayangan, khususnya punakawan (Simuh, 1999:111). Masyarakat Tengger Brang Kidul di Desa Ngadas meiliki beberapa figur sentral yang menandai keyakinan mereka pada mitos dan tradisi yang mereka miliki, yakni:

\subsubsection{Ismaya}

Pada masa keruntuhan Kerajaan Majapahit sekitar tahun 1470-1520-an, abdi keraton Sabdopalon sering dianggap sebagai titisan Semar yang diyakini mengeluarkan ramalan tentang kebangkitan kembali budaya Hindu-Buddha. Masyarakat Tengger Brang Kidul di Desa Ngadas meyakini bahwa Ismaya merupakan titisan dari kakak Dewa Siwa yang memiliki nama berbeda di tiap reinkarnasinya, seperti Semar, Humarmaya, Sabdopalon, dan Nayagenggong. Figur Ismaya juga dijiwai oleh pemikiran yang bijaksana yang direpresentasikan melalui keberadaan huruf Jawa yang memiliki arti dan esensi yang mendalam bagi kehidupan masyarakat. Figur Ismaya bahkan menjadi salah satu figur yang terdapat di altar Vihara Paramita dan diletakkan sejajar dengan patung Sang Buddha.

Dalam konteks yang lebih luas, figur Ismaya atau Semar juga memiliki arti bagi masyarakat Jawa pada umumnya. Politik Orde Baru juga mencantumkan istilah Supersemar yang menandai datangnya rezim penguasa Soeharto. Supersemar dianggap sebagai berkah Tuhan Jawa, nenek moyang ras Jawa. Kata "super" mempertegas manifestasi sifat ketuhanan yang sempurna, yakni Ismaya yang merupakan kakak dari Dewa Siwa. Stereotype Semar sebagai pendukung pemenang dimaklumi oleh masyarakat. Supersemar merupakan akronim dari Surat Perintah Sebelas Maret yang berisi perintah Presiden Soekarno pada Jenderal Soeharto untuk memulihkan ketertiban negeri, meskipun hingga saat ini tidak ada yang dapat membuktikan keberadaan surat perintah tersebut. Hal tersebut menunjukkan bahwa istilah $\mathrm{Su}-$ persemar merupakan sebuah formula yang sangat bertuah mentasbihkan kekuasaan Orde Baru (Mulder, 2001: 75-98). Semar yang menjadi simbol keadilan, kebijaksanaan, dan kebenaran diformulasikan menjadi produk Supersemar yang terkesan " $k e$ beneran" atau coincidence.

\subsubsection{Ki Kere Sabda Gedibal}

Ki Kere atau Ki Sabda Gedibal sendiri dianggap sebagai pembawa wahyu. Ia dianggap sebagai sosok yang misterius karena ia datang secara tiba-tiba dan menghilang secara tiba-tiba, sebagian masyarakat meyakini bahwa ia sudah moksa. Menurut 
cerita Ibu Jumiati, ia gemar pergi di Gunung Semeru untuk bersemedi, dalam kesehariannya hanya makan nasi jagung yang dimasak dari kukusan pertama dan makan menggunakan wadah yang terbuat dari bathok (tempurung kelapa).

"Ki Kere niku pas teko wonten mriki kula tesih timur, tiyangipun misterius, lha teko saking pundi mboten wonten sing ngertos, pas lungo nggih mboten wonten sing ngertos, tapi jarene niku moksa. Jarene niku tiyangipu saking Klaten. Rumiyin niku tiyangipun seneng semedhi wonten Gunung Semeru. Nek maem niku mboten purun ngagem piring, tapi ngagem bathok. Maemnipun namung sekul jagung, niku mawon saking kukusan sing sepindah."

(Ki Kere itu pas datang disini saya masih muda, orangnya misterius, lha datang dari mana tidak ada yang tahu, pas pergi juga tidak ada yang tahu, tetapi katanya itu moksa. Katanya orangnya berasal dari Klaten. Dulu itu orangnya suka semadi di Gunung Semeru. Kalau makan itu tidak mau memakai piring tetapi memakai tempurung kelapa. Makannya Cuma nasi jagung, itu saja dari kukusan yang pertama). (Wawancara 10 April 2015)

Ditambahkan oleh Pak Ponadi:

"Titah menika taksih tapi mboten wonten sing pertados, nek pejah mboten wonten kuburane, nek taksih kok mboten wonten tiyange, tapi mboten pejah, niku jelmaan saking Semar, tinggalane ingkang wonten mriki naming kitab Adam Makna."

(Titah (Ki Kere) tersebut masih tapi tidak ada yang percaya, jika mati tidak ada kuburannya, jika masih kok tidak ada orangnya, tapi tidak mati, itu jelmaan dari Semar, peninggalannya yang ada disini hanya kitab Adam Makna). (Wawancara 10 April 2015)

Pemeluk keyakinan Jawa Sanyata juga menyimpan filosofi hidup yang tertuang dalam etimologi huruf Jawa atau biasa disebut dengan Hanacaraka. Bagi masyarakat setempat filosofi Hanacaraka tersebut mempunyai makna yang sangat penting dan mendalam bagi masyarakat dan kehidupan. Seperti yang dikatakan Pak
Ponadi:

"Hanacaraka kala wau sanget ageng maknanipun (Hanacaraka itu tadi sangat besar maknanya), contonipun (contohnya) hanakna huripira kang sejati (tegakkanlah hidup yang sejati), hurip mung tunggu pati (hidup hanya menunggu mati), tiyang urip iki (orang hidup ini), tiyang gesang (orang hidup), orang hidup di dunia ini adalah tidak disuruh menunggu harta benda, tidak disuruh untuk menunggu wanita cantik, hanya yang ditunggu-tunggu hanya mati, tapi sebelumnya, sebelum mati itu harus hanakna huripira kang sejati (tegakkanlah hidup yang sejati), nggih bab-bab sing sae (ya halhal yang baik), perbuatan bajik kepada semua mahkluk." (Wawancara 12 April 2015)

Umat Buddha Jawa Sanyata memiliki pakaian yang khas yang digunakan saat sembahyang di Sanggar Pasembahan atau Vihara. Pakaian yang digunakan tersebut disebut berwarna hitam dengan wujud seperti jas dan dapat digunakan secara bolak-balik atau bagian dalam maupun luarnya jika dipakai sama saja. Pakaian tersebut disebut dengan kain Blimbing Walik yang mempunyai makna membalikkan atau mengembalikan yaitu mengembalikan atau membalikkan jaman seperti waktu jaman kuno, pakaian tersebut juga bermakna sebagai kesucian. Pakaian tersebut dipakai dengan rapat, padat, dan tidak tembus pandang yang mempunyai maksud agar saat mengembalikan jaman seperti jaman kuno tersebut tidak ada halangan apapun. Selain itu. pakaian tersebut melambangkan seperti terdapat dalam ungkapan kandhang langit kemul mega (rumahnya langit selimutnya awan). Ungkapan yang menggambarkan bahwa semua orang sesungguhnya tidak mempunyai rumah atau tempat tinggal. Kandhang langit itu sendiri diibaratkan sebagai sak kurebing langit sak lumahe bumi yaitu seluruh alam semesta yang hanya dimiliki atau hanya ditempati oleh Semar atau Humarmaya atau Sabdapalon atau Nayagenggong.

Selain ancestor worship, masyarakat di Desa Ngadas juga memiliki ideologi primordial sehingga kepercayaan, tradisi dan adat istiadat merka masih hidup dan bertahan hingga saat ini meskipun gem- 
puran dan tantangan zaman senantiasa membayangi kehidupan mereka. Primordial adalah ikatan-ikatan dalam masyarakat yang bersifat asli yang dibawa sejak lahir, seperti kesukuan, kekerabatan, dan keagamaan. Primordialisme merupakan perspektif yang digunakan masyarakat untuk mempertahankan etnisitas yang disuarakan oleh kaum marginal dalam suatu momen ketika mereka kehilangan kebebasannya dalam merebut hak. Primordialisme juga merupakan suatu bentuk perjuangan dalam mempertahankan identitas suatu etnik tertentu karena identitas tersebut yang memiliki peran untuk mengkomunikasikan dan memainkan harmoni suatu etnik melalui aspek bahasa, agama, bahasa, maupun peradaban yang dimilikinya. Beberapa aspek tersebut dapat diterima dengan baik sebagai suatu hal yang dianggap "suci" oleh masyarakat pendukungnya sehingga hal tersebut dikenal dengan istilah primordial (Oomenn, 2009:57-58).

Ideologi primordial terlihat dalam kehidupan masyarakat Tengger Brang Kidul di Desa Ngadas karena masyarakat masih mempertahankan identitas etnik mereka sebagai bagian dari etnik Tengger. Masyarakat di Desa Ngadas juga masih menjalankan ritual dan adat ketenggeran mereka. Masyarakat tetap mempertahankan kepercayaan asli mereka meskipun berbagai tantangan mencoba untuk menggoyahkan kepercayaan mereka. Tradisi mereka yakini bukan hanya sebagai warisan dari nenek moyang, tapi juga sebagai suatu alat dan mekanisme yang membantu menertibkan kehidupan mereka dalam bermasyarakat. Tradisi juga merupakan representasi identitas keberadaan mereka.

\section{PENUTUP}

Kehidupan beragama masyarakat Tengger Brang Kidul di Desa Ngadas tidak dapat dilepaskan dari peran pemerintah yang berusaha untuk melakukan pendisiplinan agama. Hal tersebut menimbulkan suatu hubungan dialogis dan kompromistis antara masyarakat di Desa Ngadas dengan para kaum eksternalitas yang kemudian turut ambil bagian dalam membentuk manusia Tengger hari ini. Ideologi baru dari agama yang diakui pemerintah terus menginfiltrasi kehidupan masyarakat setempat meskipun keberadaan Desa Ngadas bukan merupakan wilayah strategis yang penuh fasilitas memadai yang masih sulit dijangkau dari perkotaan. Bentuk perebutan agama dilakukan oleh masing-masing agama resmi dengan membawa klaim kebenaran sendiri dan berlomba menjadi "wadah" yang berkenan menerima masyarakat yang mau mengikuti deras arus pendisiplinan agama yang dilakukan oleh pemerintah. Permainan para agen eksternalitas dalam mengoperasikan modal yang mereka miliki hadir dalam bentuk infiltrasi Buddha Dharma dan dominasi aliran Maitreya, Bali Seering bertopeng Hindunisasi, dan infiltrasi agama Islam. Masyarakat lokal di Desa Ngadas merespon hal tersebut dengan melakukan pemertahanan ideologi lama yang mereka miliki. Pemertahanan ideologi dilakukan dengan tetap melakukan ritual dan kearifan lokal yang menjadi bagian dari warisan nenek moyang, seperti sistem kalender, beberapa ritual dan upacara keagamaan, sistem perkawinan, serta usaha dalam membentuk Forum Komunikasi Masyarakat Tengger yang bertujuan untuk menampung aspirasi dan gerakan masyarakat untuk tetap mempertahankan kepercayaan dan kebudayaan mereka sebagai bentuk resistensi terhadap kebijakan pendisiplinan agama melalui agama resmi.

Pergulatan makna terjadi dalam kehidupan masyarakat Tengger di Desa Ngadas ketika terjadi negosiasi dan kompromi antara agen eksternal berhadapan dengan masyarakat Desa Ngadas dalam sebuah arena kontestasi. Para agen memiliki keyakinan atas ideologi yang dilimikinya. Agen eksternal yakni agama resmi memiliki ideologi kebenaran absolut agama yang menganggap kebenaran agamanya memiliki kebenaran yang paling benar. Para agen eksternal tersebut memaknai bahwa agama mereka adalah agama yang paling benar dan harus disebarkan dan digunakan sebagai "wadah" bagi masyarakat Tengger di Desa Ngadas yang dianggap memiliki agama yang tidak tepat. Hal tersebut juga mempertegas adanya ideologi kekuasaan yang secara implisit menyertai proses pendisiplinan agama. Di sisi lain, masyarakat di Desa Ngadas yang mempertahankan kepercayaannya secara sadar ataupun tidak, memiliki ideologi primordial yang tetap menjalankan tradisi warisan nenek moyang.

Ideologi primordial yang dimiliki masyarakat Tengger di Desa Ngadas tidak 
dapat dianggap sebagai isapan jempol belaka. Masyarakat meyakini agama yang mereka peluk saat ini bukan hanya bermakna sebagai warisan nenek moyang, tetapi merupakan keyakinan mereka terhadap nilai dan ajaran yang mereka miliki. Masyarakat mampu memahami dan mencintai inti ajaran agama mereka sebagai bagian dari diri dan kehidupan mereka. Penelitian ini juga hendak menunjukkan bahwa masyarakat Tengger di Desa Ngadas mengetahui dan memahami atas apa yang mereka pertahankan sebagai bagian dari kesadaran dan kecintaan mereka terhadap agama yang mereka peluk secara sadar, khususnya pemeluk Buddha Jawa Sanyata. Masyarakat meyakini agama mereka sebagai cara ataupun media untuk mendekatkan diri pada Tuhan demi kedamaian. Pengendalian keinginan diajarkan melalui rasa syukur dan kontrol terhadap hawa nafsu melalui ajaran agama yang mereka yakini.

\section{DAFTAR PUSTAKA}

Arifin, Syamsul. 2005. Relevansi Gagasan Multikulturalisme dalam Masyarakat Berbeda Agama. Naskah Seminar Nasional Etika Multikultural Merajut Keindonesiaan Berlandaskan Multikultural. Surabaya 22 Oktober 2005

Baso, Ahmad. 2005. Islam Pascakolonial: Perselingkuhan Agama, Kolonialisme, dan Liberalisme. Bandung: Mizan Pustaka.

Budiwanti, Erni. 2000. Islam Sasak: Wetu Telu versus Waktu Lima. Yogyakarta: LKiS

Fashri, Fauzi. 2014. Pierre Bourdieu: Menyingkap Kuasa Simbol. Yogyakarta: Jalasutra.

Hefner, Robert W. 1999. "Geger Tengger: Perubahan Sosial dan Perkelahian Politik'. Cetakan I. Yogyakarta:
LKiS.

Hefner, Robert W. 1985. "Hindu Javanese: Tengger Tradition and Islam”. New Jersey: Princeton Univ.

Haryatmoko. 2010. Dominasi Penuh Muslihat: Akar Kekerasan dan Diskriminasi. Jakarta: Gramedia

Iyubenu, Edi AH. 2015. Berhala-berhala Wacana. Yogyakarta: IRCiSoD

Kholiludin, Tedi. 2009. Kuasa Negara Atas Agama: Politik Pengakuan Diskursus Agama Resmi, dan Diskriminasi Hak Sipil. Semarang : RaSAIL.

Mulder, Niels. 2001. Mistisisme Jawa: Ideologi di Indonesia. Yogyakarta: LKiS.

Nashir, Haedar. 1999. Agama dan Krisis Kemanusiaan Modern. Yogyakarta: Pustaka Pelaajar.

Oomenn, T.K. 2009. Kewarganegaraan, Kebangsaan, dan Etnisitas: Mendamaikan Persaingan Identitas. Bantul: Kreasi Wacana.

Soeriadiredja, Purwadi. 2012. Marapu: Agama dan Identitas Budaya Orang Umalulu, Sumba Timur. Disetasi. Depok Program Pascasarjana Antropologi, FISIP, UI.

Subagya, Rachmat. 1979. Agama dan Alam Kerohanian Asli di Indonesia. Yayasan Cipta Loka Caraka.

Suseno, Franz Magnis. 2013. Menalar Tuhan. Jogjakarta: Kanisius.

Simuh. 1999. Sufisme Jawa: Transformasi Tasawuf Islam ke Mistik Jawa. Yogyakarta: Bentang.

Widyaprakosa, S. 1994. Masyarakat Tengger: Latar Belakang Daerah Taman Nasioal Bromo. Cetakan I. Yogyakarta: Kanisius. 